\title{
PIERWSZE ODKRYCIE GROBU ROWKOWEGO $Z$ OKRESU WĘDRÓWEK LUDÓW W WIELKOPOLSCE (KONARZEWO, POW. POZNAŃ ZIEMSKI, STAN. 5)
}

\author{
FIRST DISCOVERY OF A GROOVED BURIAL FROM THE MIGRATION PERIOD \\ IN THE GREAT POLAND (KONARZEWO, POZNAŃ DISTRICT, SITE 5)
}

\author{
Tadeusz Makiewicz \\ Instytut Prahistorii, Uniwersytet im. Adama Mickiewicza \\ Św. Marcin 78, 61-809 Poznań. Poland
}

Wojciech Kaczor

Fundacja Uniwersytetu im. Adama Mickiewicza

ul. Rubież 46, 61-612 Poznań, Poland

\begin{abstract}
The article presents a discovery of the first grooved burial, rectangular in section, from the Great Poland. It is an urn burial with multiple interments; two urns with remains of three individuals are associated with a groove. Four clusters of cremated bones composed of remains of five individuals were placed directly above. Depending upon chosen interpretation, it was a burial of three or eight individuals. The burial has been dated back to the second half of the $5^{\text {th }}$ century $\mathrm{AD}$. It is a manifestation of transformations in the domain of burial rites in the last phase of the Przeworsk culture. They resulted in increasingly atypical and archaeologically indefinable forms of the burial rite. The burial was placed in the west edge of the settlement composed of hall houses made of a post construction, which was founded in the years 340-352 AD. A well cemetery with cremation burials was also discovered at this site. This was a settlement complex composed of a large settlement and at least two cremation cemeteries. It is the first complex of this type in the Przeworsk culture.
\end{abstract}

W latach 1999-2003 prowadzono badania wykopaliskowe osady kultury przeworskiej w Konarzewie, gmina Dopiewo, powiat Poznań ziemski, oznaczonej jako stanowisko 5. Prace te, realizowane w ramach ratowniczych badan archeologicznych na trasie autostrady A2, finansowane były najpierw przez Agencję Budowy i Eksploatacji Autostrad, a później, po likwidacji tej jednostki, przez Główną Dyrekcję Dróg Krajowych i Autostrad. Prace wykonywane były przez Zespół Badań Archeologicznych Instytutu Prahistorii UAM ${ }^{1}$.

\footnotetext{
${ }^{1}$ Badaniami w terenie kierował mgr Wojciech Kaczor, przy czym wstępną fazą prac kierował mgr Andrzej Michałowski, a ponadto w jednym roku prace na wschodnim odcinku prowadzil mgr Marek Żólkiewski. Konsultantem naukowym badań byl prof. dr hab. Tadeusz Makiewicz.
} 
W trakcie badań odsłonięto powierzchnię 2,43 ha, co stanowi - jak można sądzić na podstawie analizy rezultatów badań - około połowy stanowiska. Wydaje się także, że trafniej należy określić to stanowisko jako kompleks osadniczy kultury przeworskiej, gdyż poza osadą odsłonięto tutaj również wielce nietypowe cmentarzyska tej kultury.

\section{OSADA W KONARZEWIE - WSTEPNA CHARAKTERYSTYKA}

Osada w Konarzewie ${ }^{2}$ położona jest w odległości kilku kilometrów na zachód od Poznania, przy drodze prowadzącej ze wsi Konarzewo do wsi Dopiewiec. Jak już powiedziano, odsłonięto tutaj powierzchnię 2,43 ha odkrywając 2268 obiektów, w olbrzymiej większości przynależnych do kultury przeworskiej, a poza tym kilka obiektów kultury pucharków lejkowatych i amfor kulistych. Prace realizowano wyłącznie w obrębie linii rozgraniczenia autostrady.

Zasięg osady uchwycono od strony wschodniej i północnej - ciągnie się ona dalej w kierunku południowo-zachodnim. Podkreślić trzeba zdecydowanie nietypową lokalizację tej osady, która jest położona na całkowicie płaskim terenie, pozbawionym źródeł wody. Najbliższy strumień znajduje się w odległości około $2 \mathrm{~km}$ na zachód (Dopiewo) lub $1 \mathrm{~km}$ na południowy zachód.

Następnym nietypowym zjawiskiem, jest także fakt, że zarejestrowano tutaj prawie wyłącznie relikty domów halowych zbudowanych w konstrukcji słupowej, tak, że ponad $90 \%$ odsłoniętych obiektów to dołki posłupowe. Stwierdzono tylko pozostałości 3 ziemianek mieszkalnych. Jest to pierwsza $\mathbf{i}$ - jak dotychczas - jedyna osada tej kultury zabudowana prawie wyłącznie budowlami halowymi w konstrukcji słupowej. Domy halowe mają zasadniczo konstrukcję jedno- i dwunawową, ale nie można wykluczyć, że uchwycono także domy trójnawowe. W większości budynki te są doskonale czytelne, jednak w pewnym fragmencie stanowiska nakładają się na siebie relikty 4-5 budowli, zaś w innym fragmencie występuje wielkie zagęszczenie dołków słupowych, zdecydowanie utrudniające wyróżnienie zarysów domostw. W wyniku konsultacji z wybitnymi specjalistami w zakresie budownictwa halowego, dr. W. Haio Zimmermannem (Wilhelmshaven) i dr. J. Schusterem (Berlin) stwierdzono, że w obrębie osady wyróżnić można 4 lub 5 faz budowlanych. Powstanie osady datować można na lata 340-352/3 n.e., na co jednoznacznie wskazuje datowanie dendrologiczne 3 studni odkrytych w obrębie osady (ob. 1535-340 n.e.; ob. 500-346 n.e., ob. 930-352/3 n.e.) ${ }^{3}$. Ponadto odkryto ponad 20 palenisk o wyraźnie nietypowym kształcie, $\mathrm{z}$ których 19 tworzy bardzo czytelne skupienie na powierzchni 1,5 ara oraz 3 regularne jamy zasypane kamieniami, które skłonni jesteśmy interpretować jako relikty łaźni.

W materiale $z$ osady stwierdzono, po raz pierwszy na terenie Wielkopolski, ułamki nowej kategorii ceramiki, wykonywanej na kole, wyraźnie odrębnej zarówno od cerami-

\footnotetext{
${ }^{2}$ Ogólna charakterystyka osady i omówienie rezultatów badań: K a c z o r 2003.

${ }^{3}$ Datowanie dendrologiczne studni wykonane zostało przez prof. dr. hab. Marka Krapca; Kr ąpi ec 2002.
} 
ki siwej, jak i naczyń zasobowych. Nie będziemy jej tutaj bliżej omawiać, gdyż w druku znajdują się pierwsze opracowania poświęcone temu tematowi ${ }^{4}$. Wystarczy tylko stwierdzić, że ceramika taka znana jest już licznie na terenie Polski i wywodzi się z tzw. wschodnioalpejskiej, domowej ceramiki późnoantycznej (ostalpine, spätantike Hausbzw. Grobkeramik) datowanej na V i VI w. n.e., która pojawia się po roku 400 n.e. Jest ona typowa dla terenów Karyntii, Tyrolu, Słowenii i Friuli, skąd znajomość jej dotarła na ziemie polskie.

\section{GRÓB ROWKOWY (OB. 1868)}

W południowo-zachodniej części stanowiska - jak się wydaje już na skraju osady natrafiono na grób rowkowy, oznaczony jako obiekt 1868, a stanowiący fragment większego zespołu. Bezpośrednio pod warstwą współczesnego humusu wystapił luźny bruk kamienny (ryc. 1), kształtu zbliżonego do owalu, o wymiarach 12,2 ×5,4 m, ułożony z kamieni polnych, pod którymi zaległa warstwa próchniczej ziemi o miąższości sięgającej maksymalnie $0,2 \mathrm{~m}$. Już na tym poziomie, pod kamieniami bruku i warstwą ziemi, czytelny byl zarys prostokątnego obiektu rowkowego. Po wybraniu kamieni, na poziomie piaszczystego calca zarysował się wyraźnie prostokątny obiekt rowkowy, regularnego kształtu (ryc. 2), o wymiarach 2,6 × 2,2 m i szerokości rowka wynoszącej 0,22-0,64 m; jego maksymalna głębokość sięgała $0,18 \mathrm{~m}$. Wyróżniał się bardzo wyraźnie na powierzchni calca - jego wypełnisko stanowił drobnoziarnisty piasek z wielką ilością spalenizny.

Pośrodku północnego boku prostokąta, na powierzchni rowka i na osi symetrii całego założenia, znajdowały się 3 naczynia, a mianowicie: duże naczynie kształtu jajowatego, mniejsze naczynie kształtu zbliżonego do kulistego oraz wielka, bogato zdobiona waza. Dwa pierwsze naczynia zawierały przepalone kości. Na uwagę zasługuje fakt, że w rowku wypełnionym spalenizną nie znaleziono żadnych fragmentów kostnych ani innych zabytków. Przepalone szczątki kostne występowały wyłącznie w naczyniach, przy czym jedno z nich (mniejsze) było zgniecione, tak że kości zalegały wśród skorup, natomiast druga popielnica była nieuszkodzona. Przyporządkowanie kości konkretnemu naczyniu nie przysporzyło więc żadnych problemów. Wśród kości z popielnicy znaleziono 2 maleńkie ułamki grzebienia kościanego. Ponadto, na bruku i pod nim, odsłonięto 4 skupienia przepalonych kości o bardzo małej wadze. W sumie stwierdzono w całym kompleksie najprawdopodobniej 6 pochówków - $2 \mathrm{w}$ naczyniach ceramicznych oraz 4 następne w formie niewielkich skupisk przepalonych kości. Scharakteryzujemy je w dalszej części artykułu. Wśród kamieni bruku, ponad środkową partią przestrzeni otoczonej rowkiem, znaleziono fragmenty silnie skorodowanych przedmiotów żelaznych, niemożliwych obecnie do identyfikacji. Jeden $z$ takich fragmentów (bardzo drobny) stwierdzono także między kośćmi. Zostaną one pominięte w poniższych rozważaniach, gdyż znajdują się obecnie w konserwacji.

\footnotetext{
${ }^{4}$ Makiewicz 2005a; 2005 b.
} 


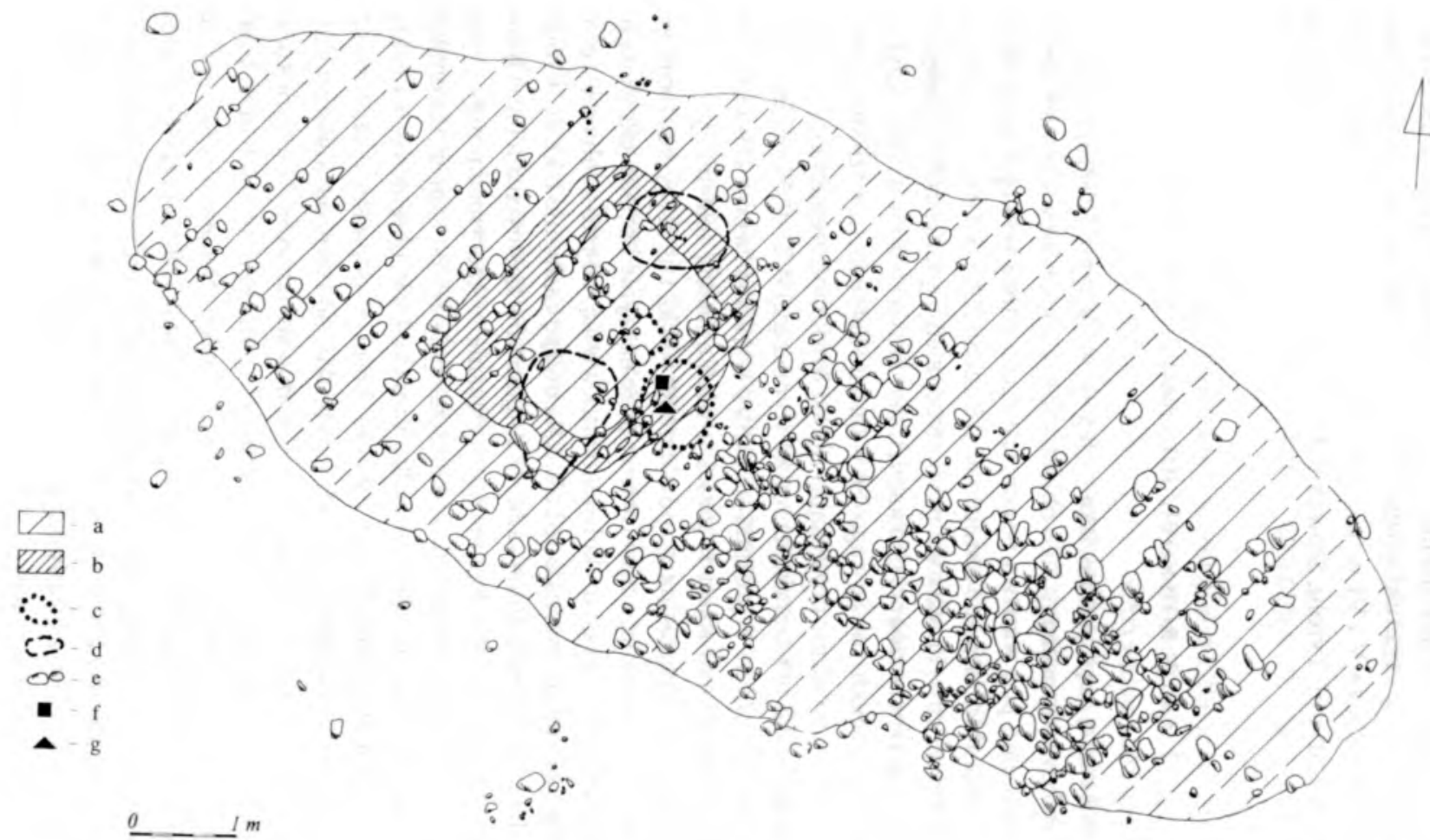

Ryc. 1. Konarzewo, stan. 5, pow. Poznan ziemski. Bruk kamienny z grobem rowkowym (ob. 1868); a - ziemia próchniczna z domieszką piasku; b - piasek ze spalenizną; c - skupienia przepalonych kości ludzkich z warstwy ziemi nad grobem; d - skupienia przepalonych kości ludzkich na bruku kamiennym; d - kamienie; $\mathrm{f}, \mathrm{g}$ - przedmioty metalowe - sprzączka i nożyk (w warstwie próchnicy ponad grobem). Rys. K. Czarnecka-Kaczor

Abb. 1. Konarzewo, Fst. 5, Landkreis Poznań. Steinpflaster mit Grabenobjekt (Obj. 1868). a - Humus mit Sandbeimischung; b - Sand mit Brandresten; c - Konzentrationen menschlichen Leichenbrandes in der Erdschicht über dem Grab; d - Konzentrationen menschlichen Leichenbrandes auf dem Steinpflaster; e - Steine; f, $g$ - Metallgegenstände - Schnalle und Messer (in der Humusschicht über dem Grab). Zeichn. K. Czarnecka-Kaczor 

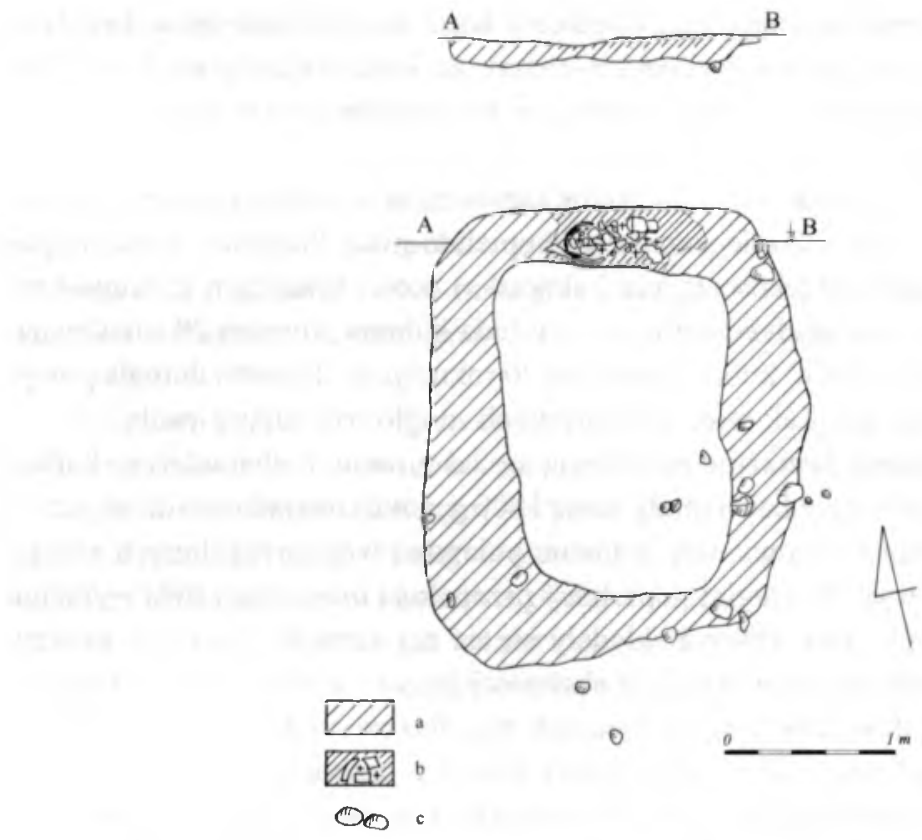

Ryc. 2. Konarzewo, stan. 5, pow. Poznań ziemski. Plan grobu rowkowego (ob. 1868); a - piasek ze spalenizną; b - grób popielnicowy - naczynia gliniane, ułamki naczyń, przepalone kości; c - kamienie. Rys. K. Czarnecka-Kaczor

Abb. 2. Konarzewo, Fst. 5, Landkreis Poznan. Plan des Grabenobjektes (obj. 1868). a - Sand mit Brandresten; b - Urnengrab - Tongefäße, Gefäßfragmente, Leichenbrand; c - Steine. Zeichn. K. Czarnecka-Kaczor

\section{WYNIKI ANALIZY ANTROPOLOGICZNEJ}

Analiza szczątków kostnych ${ }^{5}$ przyniosła bardzo ciekawe wyniki, mające wyraźny wpływ na całościową interpretację omawianego zespołu. W dużej popielnicy kształtu jajowatego wystapiła dość znaczna liczba przepalonych szczątków kostnych, bo ich łączna waga wyniosła $1800 \mathrm{~g}$. Były one barwy szarej i wykazywały średni stopień przypalenia. Rozpoznano kości z różnych okolic kręgosłupa, paliczków oraz fragmenty trzonów i nasad kości długich. Na podstawie analizy materiału stwierdzono, że kości należały do jednego osobnika. Wielkość fragmentów, ich urzeźbienie i ukształtowanie pozwalają na wnioskowanie, że są to szczątki kostne młodego mężczyzny.

Z małego naczynia-popielnicy pochodzi wyraźnie mniejsza masa kości, bo o wadze $100 \mathrm{~g}$. Były one barwy szarokremowej i wykazywały średni stopień przypalenia. Zidentyfikowano nieliczne fragmenty sklepienia czaszki o różnej grubości, fragment główki

${ }^{5}$ Ekspertyza szczątków kostnych wykonana została przez dr Elżbietę Miłosz z Instytutu Antropologii UAM; Milosz 2004. 
kości długiej osobnika młodocianego oraz fragmenty kości długich osobników dorosłych i dzieci. Na podstawie tej analizy można stwierdzić, że kości należały do dwóch lub trzech osobników, najprawdopodobniej do dorosłej kobiety (zmarłej w wieku powyżej 20 lat) i starszego dziecka - infans II/juvenis ${ }^{6}$.

Materiał ze skupisk związanych z brukiem kamiennym wygląda podobnie. Kości miały barwę popielatomleczną, mlecznoszarą i popielato-rudą. Pochodzi z nich odpowiednio $20 \mathrm{~g}$ ( 2 skupiska) i $10 \mathrm{~g}$ kości (także 2 skupiska). Kości w każdym ze skupisk reprezentowały jednego lub dwóch osobników: a) młoda kobieta powyżej 20 roku życia; b) młoda kobieta lub dziecko; c) kobieta powyżej 20 roku życia; d) osoba dorosła powyżej 20 roku życia i dziecko. Tak więc pochowanych mogło być tutaj 5 osób.

Pochówki popielnicowe wyraźnie odróżniają się od grobów o charakterze skupisk kości. I tak w jednej popielnicy kości miały masę $1800 \mathrm{~g}$, a więc wyjątkowo dużo, jak na pochówki z tego zespołu i odpowiadały dolnemu pułapowi wagi przepalonych szczątków szkieletu mężczyzny ${ }^{7}$. W drugiej popielnicy przepalona masa kości była wyraźnie mniejsza, gdyż wynosila tylko $100 \mathrm{~g}$ i skladały się na nią szczątki 2 osób - kobiety i dziecka, przy czym nie można wykluczyć obecności jeszcze jednej osoby. Natomiast masa szczątków skupisk kostnych w skupieniach była wręcz symboliczna, przy czym w jednym wypadku składały się na nią szczątki kostne 2 osobników.

Wydaje się, że na podstawie tych danych można przedstawić dwie odmienne interpretacje, dotyczące charakteru obrządku pogrzebowego i liczby pochowanych tutaj osób. Mianowicie w 4 skupieniach stwierdzono szczątki kostne młodej kobiety (4 wypadki) i dziecka ( 1 wypadek), a więc analogicznie jak w wypadku popielnicy $\mathrm{nr} 2$. Możemy więc potraktować całość jako 6 odrębnych pochówków, w których pochowano w sumie aż 8 osób, albo też stwierdzić, że w rzeczywistości mamy tutaj do czynienia z pogrzebaniem tylko 3 osób, a mianowicie młodego mężczyzny (popielnica nr 1), młodej kobiety (popielnica nr 2 i wszystkie skupienia kości) oraz 1 dziecka (popielnica $\mathrm{nr} 2$ i skupienie kości d). Szczątki kostne kobiety i dziecka znajdowałyby się więc nie tylko w popielnicy nr 2, ale także w 4 odrębnych, nie łączących się ze sobą skupieniach kości, które ponadto występowały w ziemi ponad grobem rowkowym albo zdeponowane były na bruku. W każdej z tych dwóch możliwości interpretacyjnych wymowa całości jest całkowicie odmienna i prowadzi do zupełnie innych wniosków.

W wypadku przyjęcia, że mamy tutaj do czynienia z sześcioma odmiennymi pochówkami, wyraźnie widać, że starano się niewątpliwie wyróżnić pozycję młodego mężczyzny pogrzebanego w popielnicy, ponieważ w tym przypadku zebrano - jak można sądzić - wszystkie (lub prawie wszystkie) szczątki kostne ze stosu.

W drugim pochówku popielnicowym masa kości była zdecydowanie mniejsza, natomiast w pozostałych - wręcz symboliczna. Pochówki popielnicowe wyróżnione zostały na kilka sposobów, a więc poprzez umieszczenie szczątków kostnych w popielnicy,

\footnotetext{
${ }^{6}$ Miłosz 2004.

${ }^{7} \mathrm{Na}$ temat eksperymentów z odtwarzaniem przebiegu ciałopalenia i wagi przepalonych kości ludzkich: Piontek 1976; 2002.
} 
po wtóre przez fakt umieszczenia popielnic w obrębie konstrukcji rowkowej, na jej osi symetrii, po trzecie wreszcie wyraźnie większa była w nich masa kości, przy czym pochówek szczątków męskich wybijał się tutaj wyraźnie. Natomiast pochówki umieszczone na bruku lub pod nim odznaczały się waga kości wynoszącą zaledwie $0,5-1 \%$ wagi przepalonego szkieletu, a wydaje się, że także ich położenie uznać można za wyraźnie podrzędne w stosunku do grobów głównych. Mamy więc tutaj do czynienia $z$ bardzo ciekawą sytuacją, gdyż mimo że praktycznie nie występuje żadne wyposażenie, sam kontekst sytuacyjny i masa kości pozwalają na interpretację społeczną pochówków tych osób.

Natomiast przy założeniu, że szczątki kostne kobiety i dziecka z popielnicy nr 2 oraz z 4 skupień kostnych to w rzeczywistości tylko pochówki 2 osób, mamy do czynienia $\mathrm{z}$ bardzo nietypowym i dziwnym pochówkiem. W jednej popielnicy złożono szczątki kostne mężczyzny, zaś w drugiej - niewielką część szczątków kostnych kobiety i dziecka o wadze $100 \mathrm{~g}$, co stanowi zaledwie około $3 \%$ łącznej wagi anatomicznej przepalonego na stosie szkieletu kobiecego i dziecinnego. Natomiast ponad konstrukcją rowkowa, w warstwie ziemi przykrywającej całość, a także na bruku kamiennym, złożono w 4 niezależnych skupieniach szczątki tych 2 ostatnich osób. Byłby to więc absolutnie nietypowy i niezwykły pochówek, nie mający aktualnie - jak się wydaje - żadnej analogii i będący rezultatem bardzo skomplikowanych obrzędów pogrzebowych.

Na gruncie danych archeologii i antropologii nie jest możliwe rozstrzygnięcie, z którą z tych dwóch możliwości interpretacyjnych mamy do czynienia.

\section{MATERIAL ZABYTKOWY}

Jak już stwierdziliśmy, w obrębie rowu, a właściwie na jego powierzchni znajdował się podwójny grób popielnicowy, przy czym stwierdzono tutaj 3 bardzo różne naczynia, a w 2 z nich wystappiły przypalone kości. Poza tym, w otoczeniu rowu i ponad nim, wystąpiła niewielka liczba ułamków ceramiki, zaś ponad środkową partią obiektu rowkowego, między kamieniami bruku, bardzo silnie skorodowane fragmenty żelazne, wśród nich zapewne fragmenty noża i wydłużona, owalna sprzączka żelazna. Zabytki żelazne znajdują się jednak aktualnie w konserwacji, tak że nie będą uwzględnione w niniejszym opracowaniu. Ponadto znaleziono tutaj także kilkanaście ułamków ceramiki kultury pucharów lejkowatych, pochodzących zapewne z obiektu tej kultury zniszczonego przez grób rowkowy i bruk kamienny. Materiał ten omówimy krótko w końcowej partii artykułu.

$\mathrm{Z}$ zespołu pochodzą następujące naczynia:

A. Popielnica 1

Naczynie kształtu jajowatego (ryc. 3) z krawędzią lekko wychyloną na zewnątrz i wyodrębnionym dnem. Na brzuścu, w 2/3 wysokości naczynia, dolepiony 1 guzek pseudoucho. Barwa plamista: różne odcienie brunatnej i szarobrunatnej, powierzchnia gładka, lekko szorstkawa. 


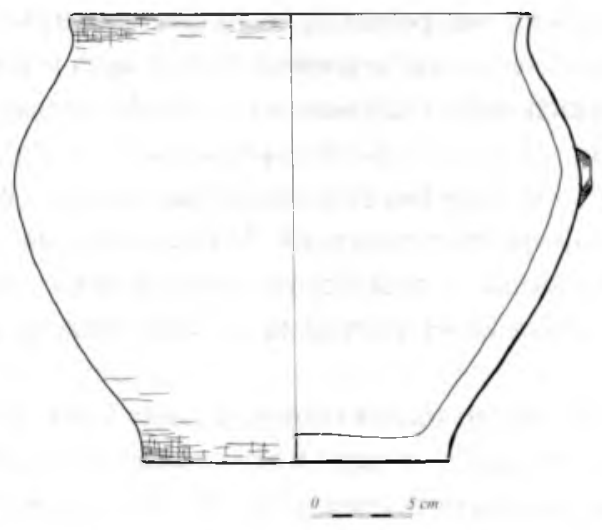

Ryc. 3. Konarzewo, stan. 5, pow. Poznań ziemski. Naczynie ceramiczne z grobu rowkowego (popielnica 1). Rys. K. Czarnecka-Kaczor

Abb. 3. Konarzewo, Fst. 5, Landkreis Poznań. Tongefäße aus dem Grabenobjekt (Ume 1).

Zeichn. K. Czamecka-Kaczor

\section{B. Popielnica 2}

Niewielkie naczynie kształtu kulistego (ryc. 4: 1), z krawędzią wyraźnie wyodrębnioną, wychyloną na zewnątrz. U nasady krawędzi znajduje się dookolna listwa, wyodrębniona od góry i od dołu dookolnymi żłobkami. Na załomie brzuśca umieszczono 3 pionowe guzki - pseudoucha. Dno wyodrębnione. Powierzchnia bardzo starannie wygładzona, barwy ciemnobrunatnej.

C. Naczynie towarzyszące

Bardzo duże naczynie kształtu wazowatego (ryc. 5), o wyraźnie zaokraglonym załomie. Krawędź lekko wychylona, niewyodrębniona, natomiast dno jest wyraźnie wyodrębnione $w$ formie nóżki. Na załomie brzuśca są 3 guzki - pseudoucha. Powierzchnia naczynia bardzo starannie wygładzona, barwy ceglastobrunatnej. Na brzuścu i w górnej partii naczynia znajduje się mało starannie wykonany ornament. Tuż nad załomem brzuśca występuje wąski pasek, utworzony przez 2 ryte żłobki dookolne, między którymi przestrzeń wypełniona jest krótkimi, rytymi kreskami ukośnymi. Poniżej załomu brzuśca zdobienie ma formę ukośnych krzyży rozmieszczonych pojedynczo lub parami; na niektórych z nich znajduje się zróżnicowana liczba pionowych, również rytych żłobków; całość ograniczona jest od dołu dookolnym rytym żłobkiem. Natomiast powyżej załomu brzuśca znajduje się ornament analogicznych ukośnych krzyży pojedynczych, z pionowymi liniami, wykonanymi jednak raczej przez wygładzanie aniżeli rycie.

Pozostałe ułamki ceramiki są mało charakterystyczne (ryc. 4: 2-9). Na uwage zasługuje fakt, że ze skupiska kości nr 1 pochodzą 3 ułamki naczyń wazowatych, silnie przypalone w ogniu, a więc okazy, które niewatpliwie znajdowały się na stosie ciałopalnym. Jak już zaznaczyliśmy, wśród kości z popielnicy były także 2 maleńkie fragmenty grzebienia kościanego trójwarstwowego. 

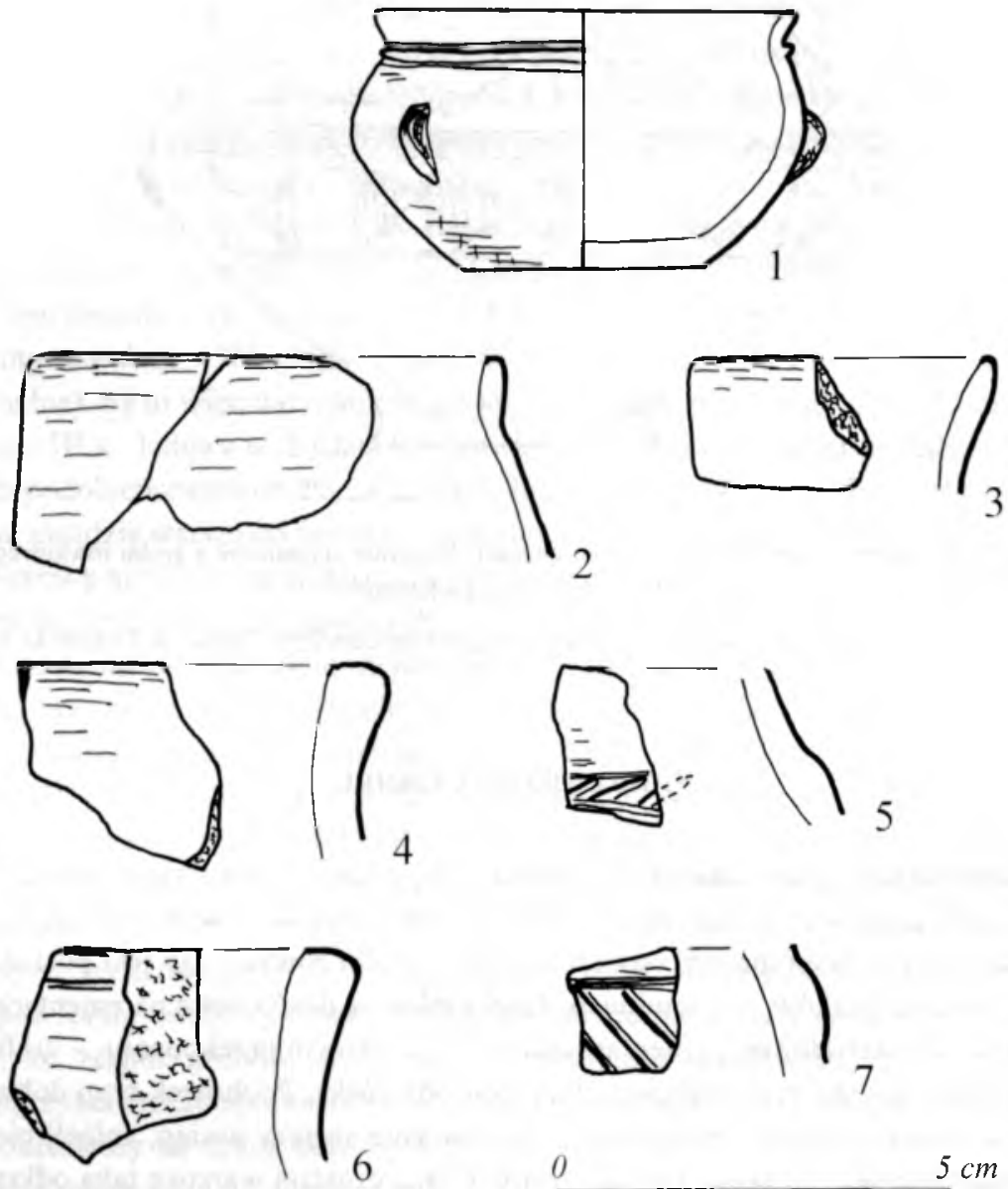

6
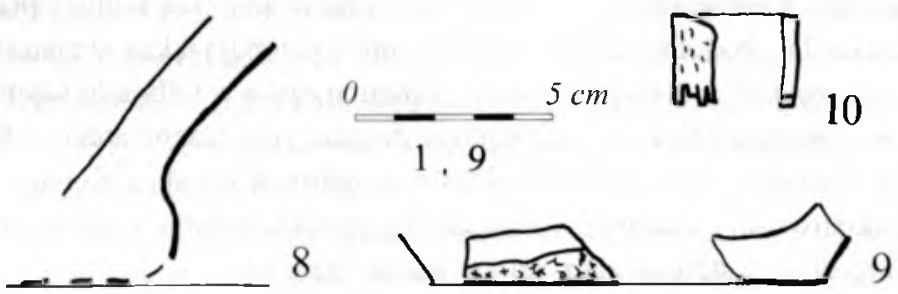

Ryc. 4. Konarzewo, stan. 5. pow. Poznań ziemski. Naczynia ceramiczne i fragment grzebienia z obiektu 1868; 1 - popielnica nr 2;2-9 - ułamki ceramiki z otoczenia obiektu rowkowego; 10 - fragment grzebienia kościanego. Rys. K. Czarnecka-Kaczor

Abb. 4. Konarzewo, Fst. 5, Landkreis Poznań. Tongefaßße und Kammfragment aus Objekt 1868. 1 - Ume 2;

2-9-Keramikfragmente aus der Umgebung von Objekt 1868; 10 - Knochenkammfragment.

Zeichn. K. Czarnecka-Kaczor 


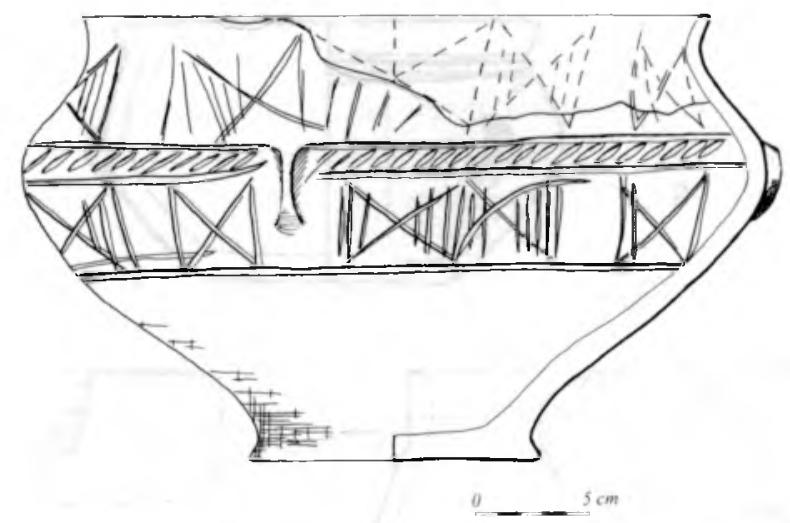

Ryc. 5. Konarzewo, stan. 5, pow. Poznań ziemski. Naczynie ceramiczne z grobu rowkowego. Rys. K. Czarnecka-Kaczor

Abb. 5. Konarzewo, Fst. 5, Landkreis Poznań. Keramikgefäß aus dem Grab. Zeichn. K. Czarnecka-Kaczor

\section{CHRONOLOGIA GROBU}

W zasadzie jedyny materiał do datowania całego zespołu stanowią w chwili obecnej naczynia gliniane, wśród których wyróżnia się naczynie wazowate, odznaczające się wielkością. Cechą wspólną wszystkich naczyń z grobu rowkowego jest posiadanie na załomie brzuśca guzków - pseudouch. Guzki takie są dość częste na cmentarzyskach tzw. grupy dobrodzieńskiej ${ }^{8}$; cmentarzyska te - w naszym przekonaniu - trafniej należałoby określić jako reprezentujące fazę dobrodzieńską. Pochówek typu dobrodzieńskiego, w postaci warstwy ciałopalenia, ma znacznie szerszy zasięg, aniżeli niewielka grupa cmentarzysk zaliczanych do tej grupy. Coraz częściej warstwę taką odkrywa się nie tylko na terenie Górnego Śląska, lecz także na Śląsku Dolnym, w Polsce Środkowej, jak i Wielkopolsce. Cmentarzyska te datowane są na późną fazę kultury przeworskiej, w zasadzie na fazę $\mathrm{D}_{1}$. Podobne naczynia z guzkami występują także w materiale ze znanych grobów książęcych w Zakrzowie oraz z cmentarzyska w Olbrachcicach ${ }^{9}$. Niektóre $\mathrm{z}$ tych naczyń wykazują pewne podobieństwo do naczynia wazowatego z Konarzewa, aczkolwiek są wyraźnie mniejsze. Pozwalałoby to datować obiekt $\mathrm{z}$ Konarzewa na faze $\mathrm{C}_{2}-\mathrm{D}$, bez możliwości uściślenia, a w naszym wypadku w ramach ogólnej chronologii całej osady, której egzystencja zaczyna się już w fazie $D_{1}$.

Wedle ogólnie przyjętych obecnie kryteriów, naczynia wazowate są typowe dla faz $\mathrm{B}_{2} \mathrm{i}_{1} \mathrm{C}_{1}$ okresu rzymskiego, a potem stają się coraz rzadsze ${ }^{10}$. Nie udało nam się znaleźć

${ }^{8}$ Szydłow ski 1974, tabl. XLVII:a; L:a, b, d, g, h; LXIII: f, g, j, k-n; CXXXV:c; CXXXVI:b-e; CXL:b; CCXXXIX:b.

${ }^{9}$ Pazda 1980 , ryc. 25:3, 4, 8, 10, 13;34:2.

${ }^{10}$ Godłowski 1981, s. 65,72 . 
ścisłej analogii do wazy z Konarzewa wśród ceramiki z młodszych zespołów kultury przeworskiej. Dotyczy to również niewielkiego naczynia kulistego - nie znaleźliśmy do niego ścisłej analogii w zespołach dobrodzieńskich i na terenie Dolnego Śląska. Trzecie naczynie - jajowate, ma dość liczne analogie zarówno na cmentarzyskach dobrodzieńskich, jak i w zespołach z najmłodszej fazy kultury przeworskiej ${ }^{11}$.

Dla interesującego nas zespołu dysponujemy jednak także datami radiowęglowymi ${ }^{12}$ i należy rozpatrzyć także datowanie uwzględniając właśnie te daty. Dla materiałów kostnych z tego zespołu wykonano w sumie 4 datowania radiowęglowe. Przyniosły one niemal identyczne daty: $1785 \pm 35 \mathrm{BP} ; 1660 \pm 40 \mathrm{BP} ; 1675 \pm 35 \mathrm{BP}$ i $1745 \pm 35 \mathrm{BP}$ (daty konwencjonalne). Są to więc daty odnoszące się w zasadzie do okresu: druga połowa Il w.

- koniec III w. Jedna z nich (data kalibrowana) jest wyraźnie młodsza, gdyż obejmuje z prawdopodobieństwem $68,2 \%$ okres $260-280$ AD i $340-430$ AD. Tak więc wszystkie one są w zasadzie starsze od momentu powstania osady. Zaznaczyliśmy już ponadto, że grób rowkowy nie może się wiązać z najstarszą fazą istnienia osady, gdyż zalegał ponad reliktami jednego z domów halowych.

Daty te są także całkowicie identyczne $\mathrm{z}$ datami uzyskanymi dla kości z warstwy ciałopalenia oraz dla węgli z wypełniska studni - ob. 1535. Z tego obiektu dysponujemy następującymi datami konwencjonalnymi ${ }^{13}$ : $1725 \pm 35 \mathrm{BP}, 1745 \pm 35 \mathrm{BP} ; 1730 \pm 30 \mathrm{BP}$; $1750 \pm 30 \mathrm{BP} ; 1670 \pm 35 \mathrm{BP}$; $1675 \pm 35 \mathrm{BP} ; 1745 \pm 35 \mathrm{BP}$. Widzimy więc, że sq one bardzo jednolite i zamykają się w czasie 80 lat, co dla egzystencji tego cmentarzyska jest raczej okresem minimalnym. Przy datowaniu kalibrowanym, z prawdopodobieństwem $68,2 \%$, daty te obejmuja okres 240-390 AD, a w jednym wypadku do $430 \mathrm{AD}$ (prawdopodobieństwo 65,9\%). W zasadniczym zrębie daty te są więc starsze od momentu powstania osady. Niemniej na ich podstawie możemy z calkowita pewnościa przyjąć, że zespół grobów związanych z obiektem rowkowym jest współczesny z cmentarzyskiem „studziennym” (ob. 1535). Początek użytkowania tego cmentarzyska określamy na drugą połowę $V$ w., najwcześniej na okres około 450-460 n.e. (kwestię tę omawiamy w odrębnej publikacji). Datowanie takie jest więc również najbardziej prawdopodobne dla grobu rowkowego. Chronologia ta może się wydawać szokująca w świetle obecnych poglądów na temat schylku kultury przeworskiej, jest jednak oparta na datownikach przyrodniczych, przede wszystkim na datach dendrologicznych. Uzyskane datowania radiowęglowe mają tę podstawową wartość, że pozwalają nam stwierdzić równoczasowość obydwu cmentarzysk, natomiast są wyraźnie starsze od dat dendrochronologicznych.

Fakt równoczesnego istnienia dwóch cmentarzysk (niezależnie od ich wielkości), związanych z osadą w Konarzewie, ma niewątpliwie ważne znaczenie dla interpretacji całościowej tego kompleksu.

${ }^{11}$ Szydłowski 1974, tabl. XLIV, XLV, XLVI:a-d, XLVII:b, XLVIII:a, e, CCL:a; Pazda 1980, ryc. $32: 2 ; 46: 4,5$.

${ }^{12}$ Datowania wykonano w Poznańskim Laboratorium Radiowęglowym; Gos lar 2004.

${ }^{13}$ Goslar 2004. 


\section{GRÓB ROWKOWY Z KONARZEWA NA TLE PORÓWNAWCZYM}

Nie ulega wątpliwości, że interesujący nas obiekt jest pierwszym odkryciem tego rodzaju na terenie Wielkopolski, czy też szerzej - na obszarze poza Małopolską i Śląskiem.

Obiekty tego rodzaju znane są z dwóch okresów interesującej nas epoki, przy czym w obydwu wypadkach zasięg ich jest bardzo ograniczony. Starsza grupa, którą datować można zasadniczo na wczesne fazy wczesnego okresu rzymskiego, a w pojedynczym wypadku również na schyłkową fazę okresu przedrzymskiego, występuje na terenie Małopolski, wzdłuż Wisły, po jej północnej stronie ${ }^{14}$, a ponadto identyczne obiekty celtyckie znane są z cmentarzyska w Kietrzu na Śląsku ${ }^{15}$. Różnią się one jednak wyraźnie od obiektów młodszej grupy, gdyż są znacząco większe $(3 \times 3 \mathrm{~m}-7 \times 7 \mathrm{~m})$. Wywodzić je można $z$ tradycji celtyckiej i raczej nie można ich genetycznie lączyć z obiektami z okresu wędrówek ludów, w tym również z obiektem z Konarzewa. Dodać można zresztą, że jak dotychczas, nie poruszano w ogóle w literaturze przedmiotu sprawy ewentualnych powiązań pomiędzy tymi dwiema odmiennymi chronologicznie grupami grobów rowkowych.

Natomiast druga grupa grobów rowkowych (ryc. 6) znana jest z cmentarzysk położonych na terenie ziemi częstochowskiej i Górnego Śląska, przy czym na 2 cmentarzyskach (Izbicko, pow. Strzelce Opolskie i Rybno, pow. Kłobuck) odkryto pojedyncze obiekty tego typu: w Opatowie, pow. Kłobuck, było ich kilka, zaś w Żabieńcu, pow. Częstochowa, odsłonięto ich kilkanaście ${ }^{16}$. Chronologię ich wiąże się z późną fazą istnienia kultury przeworskiej, czyli z fazą D. Niestety, nie zostały one dotychczas systematycznie opracowane i znane są tylko ze wstępnych opracowań i omówien.

Obiekty z Żabieńca (pow. Częstochowa) miały w większości regularny, prostokątny kształt (ryc. 7) i wymiary około $3 \times 2$ m, zaś szerokość rowka wynosiła około $60 \mathrm{~cm}$, podobnie przedstawiała się także ich głębokos $\dot{c}^{17}$. Niektóre z tych obiektów były w miarę nieregularne, zaś jeden z nich mial we wnętrzu 2 podłużne rowki, tak że wewnątrz znajdowały się aż 3 puste, prostokątne powierzchnie. W wypełnisku rowków we wszystkich obiektach występowały resztki spalonego drewna, przepalone naczynia oraz zabytki metalowe. Poniżej dna występowały często słupkowate przegłębienia, w których występowała niekiedy duża liczba przepalonych kości, fragmenty ceramiki i całe przepalone naczynia, a także przedmioty metalowe. Środkowa płaszczyzna w postaci ziemi o jasnym zabarwieniu lub czystego piasku nie zawierała żadnych zabytków. Tylko w wypadku obiektu oznaczonego numerem 17 (ryc. 8), przy krawędzi rowka lub też na obszarze

${ }^{14}$ Godłowski 1972, s. 46n.; 1980; Koperski 1972, s. 305; Gedl 1985b, s. 16ln.; Kaczanowski, Kozlowski 1998, s. 283.

${ }^{15} \mathrm{Ged} 1$ 1985a; b.

${ }^{16}$ Szydlowski 1963, s. 127; Godłowski 1964, s. 146; 1969, s. 136; 1981, s. 117; Ged1, Ginter, Godłowski 1970, s. 131, 184-187; 1971, s. 97; Kaczanowski, Kozłowski 1998, s. 285; Gedl 2002, s. 84.

${ }^{17}$ Gedl, Ginter, Godłowski 1970, s. 184n.; 1971, s. 97. 


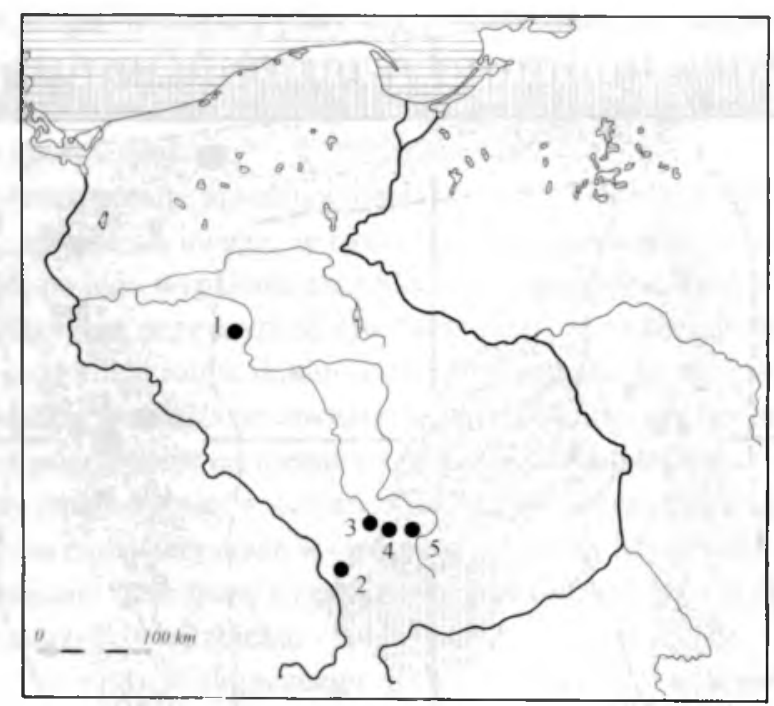

Ryc. 6. Groby rowkowe z okresu wędrówek ludów w Polsce: 1 - Konarzewo, pow. Poznań ziemski; 2 - Izbicko, pow. Strzelce Opolskie; 3 - Opatów, pow, Kłobuck; 4 - Rybno, pow. Klobuck; 5 - Źabieniec, pow. grodzki Częstochowa. Zestawił T. Makiewicz

Abb. 6. Grabenförmige Bestattungsanlagen der Völkerwanderungszeit in Polen: 1 - Konarzewo, Fst. 5, Landkreis Poznań; 2 - Izbicko, Kr. Strzelce Opolskie; 3 - Opatów, Kr. Kłobuck; 4 - Rybno, Kr. Kłobuck; 5 - Żabieniec, Kr. Częstochowa. Zusammengestellt von T. Makiewicz

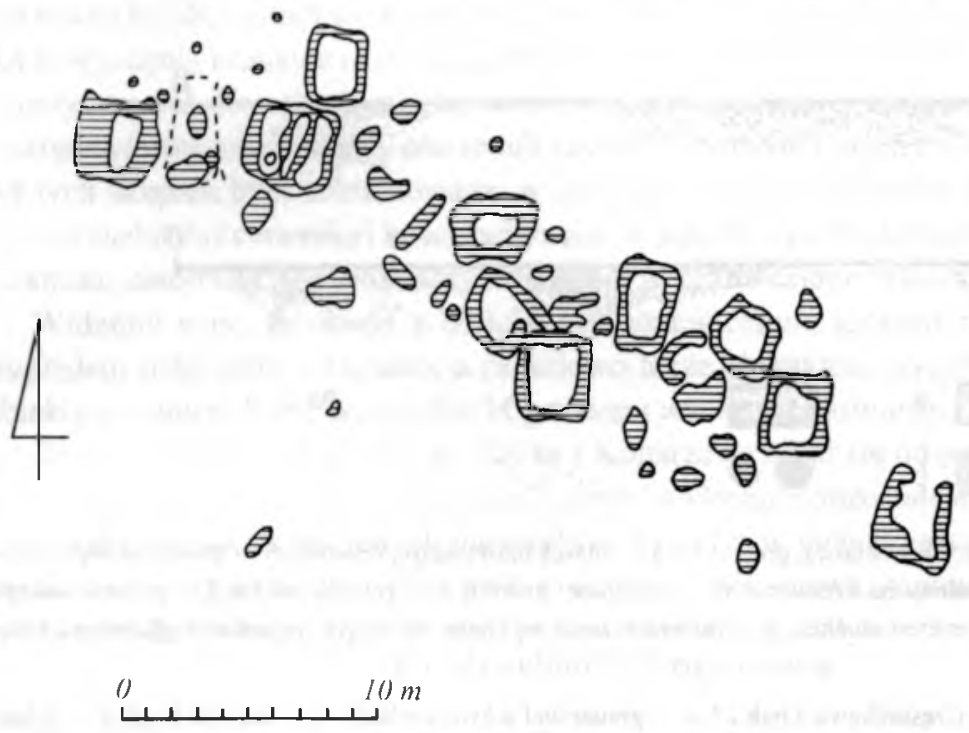

Ryc. 7. Żabieniec, pow. Częstochowa. Plan cmentarzyska kultury przeworskiej. Wg Godłowski 1969 Abb. 7. Żabieniec, Kr. Częstochowa. Plan des Gräberfeldes der Przeworsk-Kultur. Nach G o d ł o w sk 1969 

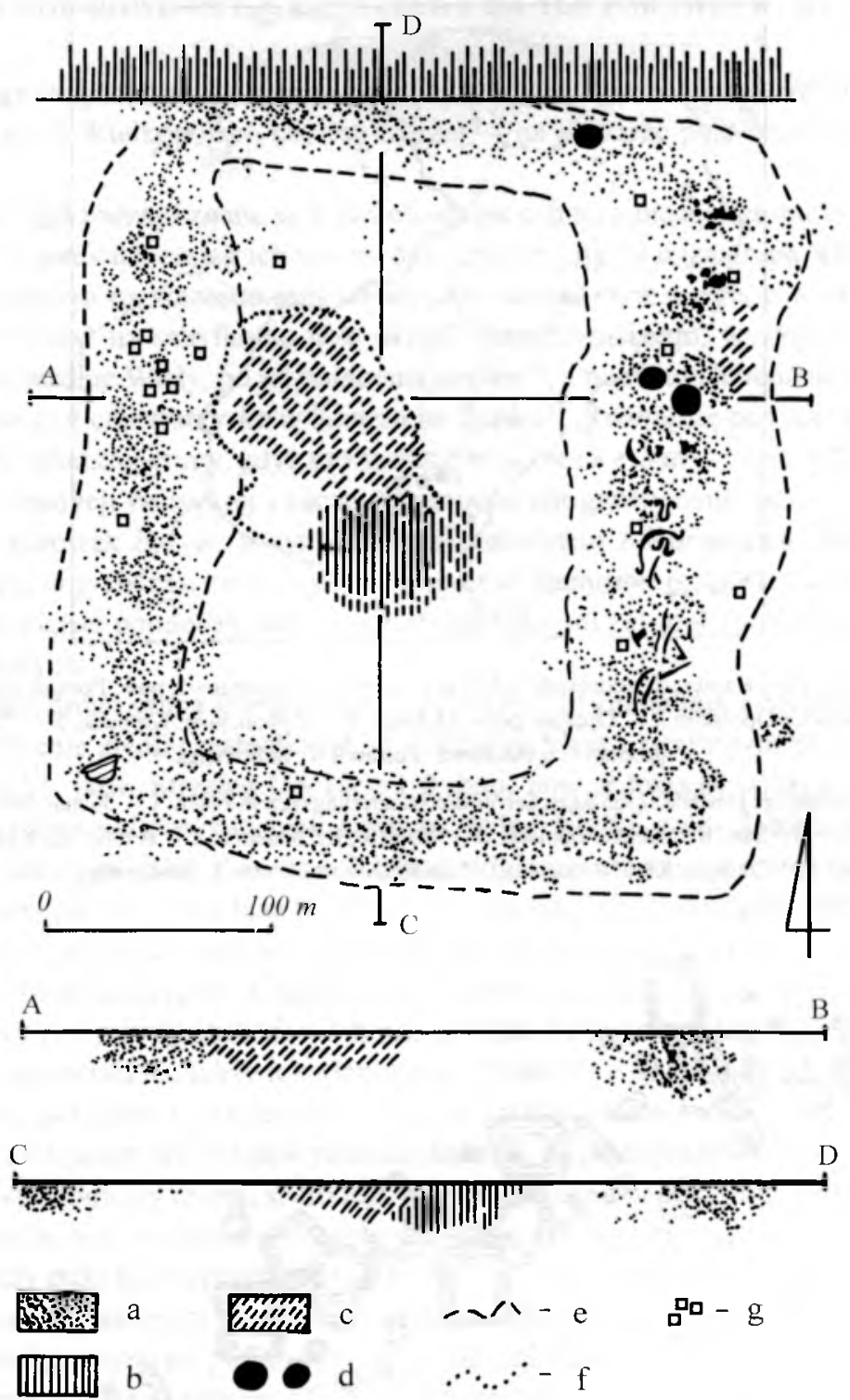

Ryc. 8. Żabieniec, pow. Częstochowa, grób nr 17; a - piasek barwy szarej i czarnej; b - piasek barwy brunatnej; $\mathrm{c}$ - piasek przepalony na czerwono; $\mathrm{d}$ - zwęglone drewno; e - granice rowka; $\mathbf{f}$ - granica zasięgu przepalonej ziemi w centrum obiektu; g - rozmieszczenie wyrobów żelaznych, przęślików glinianych i stopionego szkła. Wg Godłowski 1981

Abb. 8. Żabieniec, Kr. Częstochowa, Grab 17; a - grauer und schwarzer Sand: b - brauner Sand; c - rotgebrannter Sand; d - verkohltes Holz; e - Grabengrenze; f - Grenze des gebrannten Sandes im Zentrum des Befundes; g - Verteilung der Eisengegenstände, der Tonwirtel und geschmolzenen Glases. Nach 
otoczonym przez niego, występują płaty przepalonej ziemi na czerwono, które były śladami palenia ognia in situ ${ }^{18}$. Niektóre z grobów zawierały, jak wykazały to analizy antropologiczne, szczątki jednego zmarłego (m.in. ob. 17), zaś w innych występowały szczątki kostne kilku osobników.

We wstępnej interpretacji przedstawionej przez K. Godłowskiego i powtórzonej przez M. Gedla ${ }^{19}$, zwraca się uwagę, że rowek otaczał prawdopodobne miejsce palenia stosu ciałopalnego, po jego wypaleniu szczątki tegoż stosu wraz z zabytkami zgarniano do otaczającego stos rowu, przy czym M. Gedl stwierdza, że na przestrzeni obwiedzionej rowkiem co najmniej kilkakrotnie dokonywano ciałopalenia. Interpretacja taka wydaje się mało przekonująca. Stwierdza on również, że ludność kultury przeworskiej w Żabień$\mathrm{cu}$, miała obyczaje pogrzebowe odmienne od rozpowszechnionych w tej kulturze. Natomiast użytkownicy cmentarzyska w Żabieńcu utrzymywali kontakty z sąsiadami, którzy grzebali zmarłych na cmentarzyskach w Opatowie i Rybnie. Istniały też jakieś powiązania pomiędzy okolicami dzisiejszej Częstochowy a okolicami Strzelc Opolskich, gdzie znajduje się cmentarzysko w Izbicku.

W kontekście odkrycia analogicznego grobu na terenie Wielkopolski, koncepcja ścisłych powiązań pomiędzy poszczególnymi rejonami, w których występowały tego rodzaju groby, nie jest już oczywiście aktualna. Należy zwrócić uwagę, że już wcześniej świadczyły o tym wyraźne różnice w charakterze poszczególnych grobów, na które nie zwracano stosownej uwagi.

Na szczególną uwagę zasługuje obiekt w Izbicku (ryc. 9), powiat Strzelce Opolskie ${ }^{20}$. Miał on wymiary $2,2 \times 2,4 \mathrm{~m}$ (a więc prawie identyczne jak obiekt $\mathrm{z}$ Konarzewa), zaś rowek został uchwycony tuż pod warstwą współczesnego humusu. Zabarwienie wypełniska rowku było niejednolite, w zależności od zawartości spalenizny i węgla. Na głębokości $0,4 \mathrm{~m}$ wystąpiły brunatne i ciemnoszare plamy, sięgające do $0,55 \mathrm{~m}$, których wypełnisko tworzył węgiel. Rowek sięgal głębokości $0,5-0,8 \mathrm{~m}$. Tylko w obrębie rowu wystąpiło 5 skupień kości o niewielkiej wadze lub zgoła symbolicznej liczbie. Zawartość kulturowa tych skupień była zróżnicowana; w jednym skupisku wystąpiła zapinka, przęślik, grudka żużla oraz ceramika i kości zwierzęce. W innym szydło, blaszka brązowa i ułamki ceramiki, natomiast w 3 pozostałych, obok kości, znaleziono tylko ułamki ceramiki.

Widzimy więc, że obiekt $\mathrm{z}$ Izbicka jest analogiczny $\mathrm{z}$ grobem $\mathrm{z}$ Konarzewa pod względem rozmiarów i ksztaltu, a częściowo także charakteru wypełniska. Natomiast obiekty z Żabieńca wyróżniają się bogactwem zawartości kulturowej.

W sumie stwierdzić można, że obiekt z Konarzewa różni się od pozostałych trzema cechami. Po pierwsze, w wypełnisku wystapiły wyłącznie pozostałości spalenizny, bez domieszki jakichkolwiek innych materiałów. Nie było w nich ani szczątków kostnych, ani ułamków ceramiki. Po wtóre, grób rowkowy z Konarzewa stanowił de facto rodzaj grobu popielnicowego, gdyż na jego powierzchni znajdowały się 3 naczynia gliniane,

\footnotetext{
${ }^{18}$ Gedl, Ginter, Godłowski 1971, s. 97.

${ }^{19} \mathrm{Gedl} 2002$.

${ }^{20}$ Szydtowski 1963, s. 127, 139.
} 


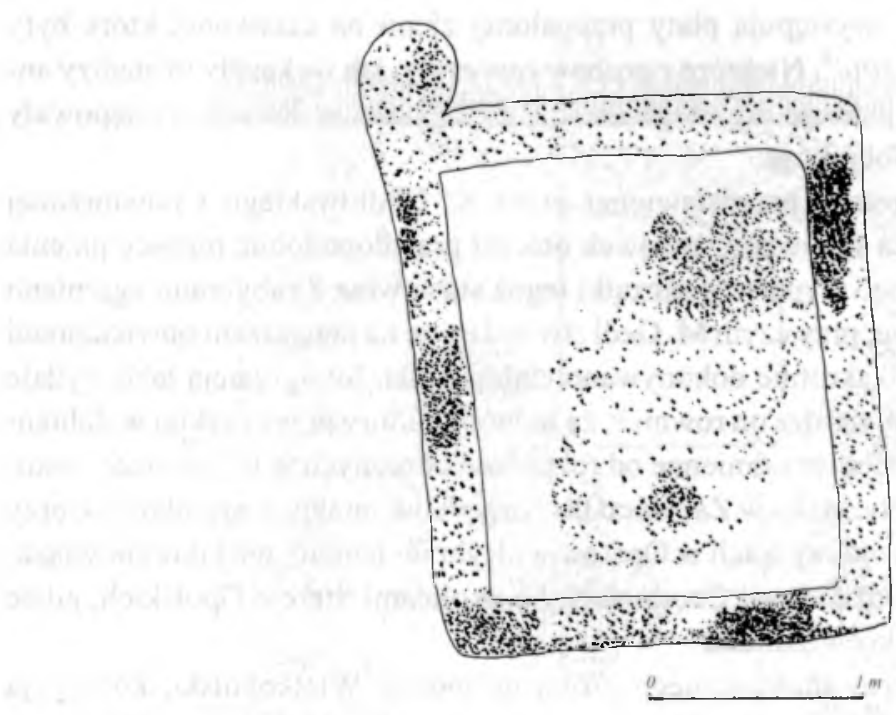

Ryc. 9. Izbicko, pow. Strzelce Opolskie, grób 50. Zarys jamy grobowej. Wg Szydłowski 1963 Abb. 9. Izbicko, Kr. Strzelce Opolskie, Grab 50. Umriß der Grabgrube. Nach S zy dłow sk i 1963

w tym 2 popielnice. Ponadto obiekt z Konarzewa wyróżniał się jeszcze tym, że był przykryty brukiem kamiennym.

Nie ulega wątpliwości, że omawiane groby to obiekty jednego rodzaju, o wręcz identycznym kształcie, wymiarach, a po części także charakterze wypełniska. Są natomiast wyraźnie zróżnicowane pod względem charakteru pochówków oraz wyposażenia.

W odniesieniu do postawionej wcześniej interpretacji, że mamy tutaj zapewne do czynienia z miejscami kremacji, z których następnie zgarniano szczątki ciałopalenia, szczątki kostne, ceramikę i inne dary grobowe do rowków otaczających stos, stwierdzić trzeba, że interpretacja taka budzi poważne wątpliwości. Glówną podstawą do sformułowania takiej hipotezy była sytuacja z grobu $\mathrm{nr} 17 \mathrm{w}$ Żabieńcu, gdzie w obrębie przestrzeni otoczonej rowkiem wystąpił płat przepalonej ziemi. Był to jednak jedyny taki przypadek. Trzeba ponadto zwrócić uwagę na fakt, że zajmował on tylko nieznaczną część tej przestrzeni, a zidentyfikowano tutaj szczątki tylko jednej osoby. W wypadku części obiektów z Żabieńca oraz obiektu z Izbicy stwierdzono obecność słupkowatych przegłębien, w których poza spalenizną występowały kości ludzkie, ułamki ceramiki, a także zabytki metalowe. Świadczy to wyraźnie o tym, że są to odrębne pochówki w obrębie rowu, który - jak z tego wynika - od początku stanowił rodzaj grobu zbiorowego, gdyż nie zaobserwowano tutaj faktu wtórnego wkopywania tych przegłębień, w ramach już istniejących grobów. Zbliżona w pewnym sensie jest sytuacja w Konarzewie, gdzie poza pochówkami 3 osób w popielnicach. ponad grobem - rowkiem wystąpiły 4 skupienia kości z pochówkami 5 osób, przy czym 2 znajdowały się na bruku kamiennym. Jest więc i tutaj wielopochówkowość, wyrażająca się jednak w odrębnej formie. 
W rzeczywistości mamy więc tutaj do czynienia z odrębnym typem obrządku pogrzebowego, będącym jednym z elementów silnej i zróżnicowanej wewnętrznie ewolucji i zmian form obrządku pogrzebowego kultury przeworskiej w jej młodszej fazie, który od warstwowych cmentarzysk dobrodzieńskich prowadzi do coraz dziwniejszych i coraz mniej oczywistych form tego obrządku.

Zwróćmy ponadto uwagę, że jak na obiekty, w których dokonywać miano kilkakrotnego obrzędu ciałopalenia, ilość szczątków kostnych, ułamków ceramiki i innych darów grobowych (w większości obiektów), a także samych szczątków stosu jest zdumiewająco niewielka. Niezależnie zresztą od faktu, czy groby te powstały w rezultacie prostego zgarnięcia szczątków stosu ciałopalnego do rowka otaczającego stos, czy też mamy do czynienia z przeniesieniem i złożeniem części szczątków ciałopalnych do przygotowanego uprzednio rowka, nie majacego związku ze stosem ciałopalnym, nie ulega watpliwości, że są to celowe groby jedno- lub wielopochówkowe. Potwierdza to z pewnością obiekt z Konarzewa, gdzie w grobie, w obrębie rowka, złożono tylko spaleniznę ze stosu ciałopalnego, a szczątki kostne złożono w popielnicach, natomiast pozostałe pochówki na bruku lub pod nim.

Niezależnie od tego, którą wersję interpretacyjną uznamy za bardziej przekonująca, jest jasne, że mamy tutaj do czynienia ze zjawiskami dotychczas nieznanymi w charakterze obrządku pogrzebowego kultury przeworskiej.

Odkrycie w Konarzewie pozwala jednocześnie na stwierdzenie, że groby rowkowe, wbrew dotychczasowym ujęciom, nie byly tylko zjawiskiem regionalnym, o bardzo ograniczonym zasięgu lokalnym. Obiekt z Konarzewa sugeruje poza tym wyraźnie młodszą chronologię całego zjawiska, aniżeli to dotychczas przyjmowano.

Stwierdzić można, że mamy tutaj do czynienia z grupa grobów o oryginalnym charakterze, będącą wyraźnym przejawem zmian w obrządku pogrzebowym w późnej fazie kultury przeworskiej, i że zmiany te prowadzą do coraz trudniej uchwytnych archeologicznie form obrządku pogrzebowego.

\section{CERAMIKA KULTURY PUCHARÓW LEJKOWATYCH}

Jak już stwierdziliśmy, w warstwie ziemi próchnicznej zalegającej pod brukiem kamiennym, a ponad obiektem rowkowym znaleziono także 11 fragmentów ceramiki kultury pucharów lejkowatych. Najprawdopodobniej uznać je można za pozostałość jakiegoś niewielkiego obiektu tej kultury, który został zniszczony przy budowie grobu rowkowego lub bruku kamiennego. Skorupy te są niezwykle jednorodne pod względem technologiczno-stylistycznym i z całą pewnością uznać je można za pochodzące z $3-4$ naczyń.

Wszystkie ulamki ceramiki mialy silnie zniszczone, wymyte powierzchnie, przez co były szorstkie i ostre w dotyku. Pochodzily ze stosunkowo cienkościennych naczyń, w przełomie barwy czarnej lub ciemnoszarej. Wykonano je z gliny zawierającej domieszkę schudzającą drobno- lub średnioziarnistego tłucznia ceramicznego (tzw. szamotu). 

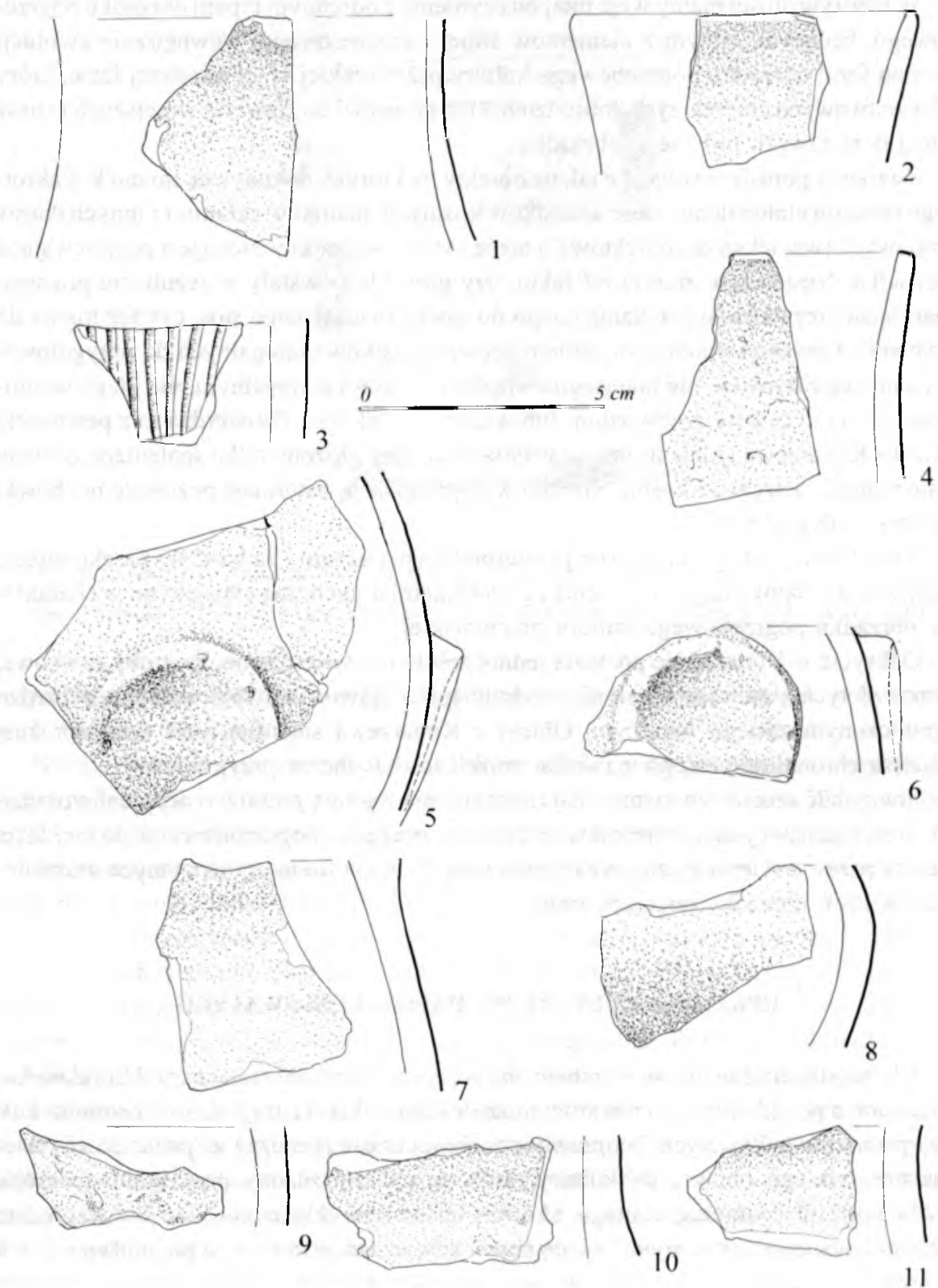

Ryc. 10. Konarzewo, stan. 5, pow. Poznań ziemski. Ceramika kultury pucharów lejkowatych z otoczenia obiektu rowkowego (ob. 1868). Rys. J. Sawicka

Abb. 10. Konarzewo, Fst. 5, Landkreis Poznań. Keramik der Trichterbecherkultur aus der Umgebung der Grabenanlage (Obj. 1868). Zeichn. J. Sawicka 
Omawiany zbiór jest spójny pod względem cech stylistycznych. Niewiele można powiedzieć o formach naczyń, ale dwa z nich miały z pewnością szyjki ukształtowane lejkowato (ryc. 10;2,4), a szyjka trzeciego zwężała się zapewne stożkowato ku górze (ryc. 10;1). Na trzech fragmentach występowało zdobienie, przy czym w dwóch wypadkach były to plastyczne listewki w kształcie odwróconej litery U (ryc. 10; 5, 6). Listwy te z pewnością pełniły funkcję uchwytów, ale zapewne miały też znaczenie zdobnicze. Inny ułamek byl pokryty w całości pionowymi, dość płytkimi liniami rytymi (ryc. 10; 3).

Przedstawione cechy stylistyczne, choć ubogie, można dość jednoznacznie kojarzyć z późnym odcinkiem istnienia kultury pucharów lejkowatych, gdy ta kultura rozwijała się w warunkach silnych oddziaływań południowych, z kręgu kultury promienistej. Przejawiały się one w sferze technologii poprzez stosowanie domieszki gruboziarnistego tłucznia ceramicznego, a w sferze zdobnictwa - udziałem pionowych elementów zdobniczych i skośnych linii rytych. Materiały te mają analogie w zespołach z terenu Wielkopolski, określanych jako grupa mrowińska ${ }^{21}$ kultury pucharów lejkowatych, typowych dla obszaru Wielkopolski na zachód od Warty, wiązanych z oddziaływaniami szeroko pojętego kręgu kultury badeńskiej.

\section{BIBLIOGRAFIA}

\section{Ged1 M.}

1985a Obiekty rowkowe na cmentarzysku z okresu lateńskiego i wczesnego okresu wplywów rzymskich w potudniowej Polsce, I [Zus.: Grabenobjekte aus der La Tène- und der frühen Kaiserzeit in Südpolen. I], „Przegląd Archeologiczny” t. 32, s. 157-186.

1985b Obiekty rowkowe na cmentarzysku z okresu lateńskiego i wczesnego okresu rzymskiego w poludniowej Polsce, II [Zus.: Grabenförmige Objekte aus der La Tène - und der frühen Kaiserzeit in Südpolen. II], „Przegląd Archeologiczny” t. 33, s. 159-190.

2002 Częstochowa. Dzieje miasta i klasztoru jasnogórskiego. Okres staropolski, t. 1, Częstochowa, s. 57-95.

Gedl M., Ginter B., Godłowski K.

1970 Pradzieje i wczesne średniowiecze dorzecza Liswarty, cz. 1 [Sum.: Prehistory and the Early Middle Ages in the Liswarta River Basin, Part I], Katowice.

1971 Pradzieje i wczesne średniowiecze dorzecza Liswarty, cz. 2 [Sum.: Prehistory and the Early Middle Ages in the Liswarta River Basin, Part II], Katowice.

Godłowski K.

1964 Sprawozdanie z badań wykopaliskowych w Opatowie, pow. Klobuck w 1962 roku [Sum.: Report on the Excavations at Opatów, District of Klobuck, in 1962], „Sprawozdania Archeologiczne” t. 16 , s. $142-148$.

1969 Kontynuacja badań wykopaliskowych w dorzeczu Liswarty (Rybno ${ }_{2}$ Żabieniec, Opatów) [Sum.: Continued Excavations in the Liswarta Basin (Rybno, Żabieniec, Opatów)], ,Sprawozdania Archeologiczne" t. 21, s. 135-152.

${ }^{21}$ Charakterystyka tej grupy i najbliższe analogie, a także dalsza literatura patrz: Prinke, Przybył, Chachlikowski, Kabaciński 2002, s. 17n. Autorzy chcieliby podziękować dr. Jackowi Wierzbickiemu za pomoc $w$ interpretacji charakteru tej ceramiki. 
1972 Badania na cmentarzysku z okresu rzymskiego w Kryspinowie [Sum.: Investigations of the Cemetery of the Roman Period of Kryspinów, Cracow District], „Sprawozdania Archeologiczne” t. 24. s. $129-148$.

1981 Kultura przeworska, (w:) Prahistoria ziem polskich, t. V: Późny okres lateński i okres rzymski, red. J. Wielowiejski, Wrocław-Warszawa-Kraków-Gdańsk, s. 57-135.

Goslar T.

2004 Raport $z$ wykonania datowań C-14 w Poznańskim Laboratorium Radiowęglowym, Numer Projektu 444/04 (maszynopis ekspertyzy).

Kaczanowski P., Kozłowski J.K.

1998 Najdawniejsze dzieje ziem polskich, Kraków.

$\mathrm{Kaczor} W$.

2003 Archeologiczne badania ratunkowe na wielokulturowym stanowisku nr 5 (A 2-135) w Konarzewie, pow. poznaniski, woj. wielkopolskie [Zus.: Archäologische Rettungsausgrabungen auf dem Mehrkulturfundstelle Nr. 5 (A2-135) in Konarzewo, Kreis Poznań, Woj. Wielkopolskie], „Wielkopolskie Sprawozdania Archeologiczne" t. 6, s. 293-299.

Koperski A.

1972 Badania archeologiczne w Trójczycach, pow. Przemyśl, w latach 1967-1970 [Sum.: Excavations at Trójczyce, Przemyśl District, in 1967-1970], ,.Sprawozdania Archeologiczne” t. , s. 299-306.

Krąpiec M.

2002 Wyniki analizy dendrochronologicznej prób drewna z badań na trasie autostrady A-2 (Konarzewo st. 5 i Stugocinek, st. 13) (maszynopis opracowania).

Makiewicz T.

2005a Die Entdeckung einer neuen Kategorie der Keramik aus der Völkerwanderungszeit in Großpolen, (w:) Festschrift Rosemarie Müller, Ergänzungsband der Hoops Reallexikon der Germanischen Altertumskunde, Bd. 42, Berlin-New York.

2005b O tak zwanej „,ceramice późnośredniowiecznej” "w Polsce [Zus.: Zur sogenannten „pseudomittelalterlichen Keramik” in Polen], „Archaeologia Historica Polona” t. 15 (w druku).

Miłosz E.

2004 Analiza antropologiczna materialów kostnych z Konarzewa (ob. 1868) (maszynopis opracowania).

Pazda S.

1980 Studia nad rozwojem i zróżnicowaniem lokalnym kultury przeworskiej na Dolnym Ślasku [Zus.: Studien über die Entwicklung und lokale Differenzierung der Przeworsk - Kultur in Niederschlesien], Wrocław.

Piontek J.

1976 Proces kremacji i jego wplyw na morfologię kości w świetle wyników badań eksperymentalnych

[Sum.: The Process of Cremation and its Influence on the Morphology of Bones in the Light of Results of Experimental Research], „Archeologia Polski” t. 21, s. 255-277.

2002 Wplyw procesu kremacji na morfologię kości szkieletu ludzkiego. Wyniki badan eksperymentalnych, (w:) Popiót i kość. Funeralia lednickie 4 (red. J. Wrzesiński), Sobótka - Wroclaw.

Prinke D., Przybył A., Chachlikowski P., Kabaciński P.

2002 Obiekt kultury pucharów lejkowatych (39) w Szczuczynie, gm. Szamotuty, stan. 5 - na tle wstępnych wyników badań stanowiska wielokulturowego, (w:) Badania archeologiczne ziemi szamotulskiej, cz. I, red. H. Machajewski, R. Pietrzak, Poznań, s. 7-44.

Szydłowski J.

1963 Cmentarzysko późnorzymskie w Izbicku, pow. Strzelce Opolskie [Zus.: Spätrömische Grabstätten in Izbicko, Kr. Strzelce Opolskie], „Silesia Antiqua” t. 5, s. 106-141.

1974 Trzy cmentarzyska typu dobrodzieńskiego, Tablice, „Rocznik Muzeum Górnośląskiego w Bytomiu" t. 5, Bytom. 


\section{DIE ERSTE ENTDECKUNG EINES GRABENFÖRMIGEN SEPULKRALOBJEKTES DER VÖLKERWANDERUNGSZEIT IN GROSSPOLEN (KONARZEWO, FST. 5, LANDKREIS POZNAN)}

\section{Zusammenfassung}

In den Jahren 19992003 wurden auf dem Gelände einer völkerwanderungszeitlichen Siedlung der Przeworsk-Kultur in Konarzewo bei Poznań Rettungsgrabungen durchgeführt. In ihrem Verlauf wurde cine Fläche von 2,3 ha aufgedeckt, was sicher der Hälfte des besiedelten Geländes entspricht. Die Siedlung verdient in mehrerer Hinsicht Aufmerksamkeit. Erstens ist es gegenwärtig die einzige, deren Gründungszeit präzise mit Jahresgenauigkeit datiert werden kann. Auf der Grundlage von Eichenhölzern aus drei Brunnen kann man folgern, daß sie in den Jahren 340 352/3 u.Z. entstand (Obj. 1553: 340 u.Z., Obj. 500: 346 u.Z., Obj. 930: 352/3 u.Z.). Zweitens besteht sie fast ausschließlich aus Langhäusern in Pfostenbauwcise. Bisher sind nur zwei derartige Bauten aus Polen bekannt. Auf der Basis von Analysen und Konsultationen mit Spezialisten (Dr. W. Haio Zimmermann, Wilhelmshaven, und Dr. Jan Schuster, Berlin) kann man hier vier oder fünf Bauphasen herausstellen. Drittens wurde hier eine neue Kategorie scheibengedrehter Keramik festgestellt. Diese ist mit der von B. von Richthofen in den Jahren 1926-1928 herausgearbeiteten sog. pseudomittelalterlichen Keramik und der von W. Boege 1938 beschriebenen Keramik identisch. Weitere Untersuchungen zeigten, daß man sie auf spätantike ostalpine Keramik zurückführen kann, welche in das 5. und 6. Jh. datiert und typisch für Kărnten, Tirol, Slowenien und der Region um Friaul in Italien ist. Viertens schließlich wurde in einem der Brunnen eine Leichenbrandschicht mit einer Mächtigkeit von $55 \mathrm{~cm}$ entdeckt. Es handelt sich um einen Brandbestattungsplatz, der erste dieser Art in Europa, dessen Einsetzen man in die zweite Hälfte des 5. Jhs. datieren kann.

Am nordwestlichen Siedlungsrand wurde ein mit der Nummer 1868 bezeichnetes Grabenobjckt freigelegt. Dieses hatte eine regelmäßige, rechteckige Form mit den Maßen 2,6 × 2,2 m. Die Breite des Gräbchens betrug 0,6-1,2 m, seine Tiefe 0,18 m. An der Grabenoberfläche, im nördlichen Teil auf der Symmetrieachse, befanden sich drei Gefäße, von denen zwei Umen waren. Das dritte (eine große Schale) deckte sie ab. Die gesamte Anlage war von einem ovalen Steinpflaster bedeckt. Im Gräbchen trat ausschließlich Branderde ohne irgendwelche Keramikfragmente. Knochen oder andere Funde auf. Über dem Grab fand man Keramikfragmente und zwei Leichenbrandkonzentrationen sowie zwei Eisengegenstände - Schnalle und Messer, welche in dieser Publikation nicht besprochen werden (Konservierung). Außerdem existierten zwei identische Leichenbrandkonzentrationen über dem Grab, auf dem Steinpflaster

In eine der Urnen war der Leichenbrand eines jungen Mannes (Gew. 1800 g) gefüllt worden, in die zweite der einer jungen Frau und eines Kindes (Infans 11/Juvenis) von zusammen 100 g. Das Gewicht der Leichenbrände über dem Grab betrug 10 bzw. $20 \mathrm{~g}$. Es handelt sich um vier Frauen, in einer Konzentration fand man zudem Knochenreste eines Kindes.

\section{Der Charakter der Bestattungssitte}

Auf Grundlage der oben beschriebenen Befundsituation und der Ergebnisse des anthropologischen Gutachtens kann man zu zwei verschiedenen Deutungen kommen: Es ist zu vermuten, daß a) mit drei Personen oder b) mit sogar acht Personen zu rechnen ist, die hier bestattet wurden. Im ersten Fall wurde in einer der Umen ein junger Mann beigesetzt, wobei das Leichenbrandgewicht an der unteren Normgrenze liegt (oder sich ihr annähert), in der zweiten Urne eine Frau (Ehefrau) mit Kind, wobei das Knochengewicht jedoch nur ca. 3\% des anatomischen Gewichts des Leichenbrandes einer Frau und eines Kindes beträgt. Die übrigen Leichenbrandkonzentrationen bestehen aus den Knochenresten derselben Frau (vier Stellen) und des Kindes (eine Stelle). Deutlich ist dann die Position des Mannes hervorgehoben. hingegen wurde die Frau an fünf Stellen begraben, das Kind an zweien. Wir haben es somit mit sehr untypischen und merkwürdigen Gräbern zu tun.

Bei der zweiten Deutung wäre jede Stelle Bestattungsplatz einer anderen Person. In einer Urne wurde ein Mann beigesetzt, in der zweiten bestattete man eine Frau mit Kind (sicher Ehefrau und Kind des Mannes), an 
den Stellen über dem Grab und auf dem Steinpflaster in symbolischer Menge $0,5-1 \%$ des anatomischen Gewichts) die Kochenreste von vier Frauen und einem Kind. In diesem Falle wurden die Positionen der in den Urnen im Graben Bestatteten hervorgehoben (besonders die des Mannes) und entschieden untergeordnet wurden die Personen behandelt, deren Knochenreste man außerhalb des Grabens fand (Bedienstete, Sklaven). Es ist sehr interessant, daß, trotz des Fehlens von Ausstattung, allein die Befundsituation und das Leichenbrandgewicht Rückschlüsse auf die gesellschaftliche Position der hier bestatteten Personen erlaubt. Auf der Grundlage der archäologischen und anthropologischen Daten ist nicht zu entscheiden, welcher der vorgestellten Interpretationen der Vorzug zu geben ist.

\section{Die Chronologie des Grabes}

Die Datierungsgrundlage sind zur Zeit die Tongefäße (die Metalle befinden sich in der Konservierung). Es handelt sich um eine große. reich verzierte Vase, um einen eiförmigen Topf und ein kleines kugelförmiges Gefäß. Alle Gefäße besitzen kleine Pseudohenkel. Das vasenförmige Gefäß wird als typisch vor allem für die Phasen B2-Cl erachtet. Jedoch haben die knopfartigen Pseudohenkel Parallelen in der Keramik der Dobrodzień-Gruppe und in Niederschlesien der Phase D. Das würde eine Datierung in die Phase D erlauben (die Siedlung wurde in den Jahren 340-352/3 gegründet, also zu Beginn dieser Phase). Jedoch überschnitt das Grab ein Langhaus und kann damit nicht mit der frühesten Phase der Siedlung verbunden sein. Überdies verfügen wir für das Grab über vier C14-Daten: 1785-1660 B.P; analoge Daten wurden für den Bestattungsplatz im Brunnen (Obj. 1535) gewonnen. Man muß folgern. daß die Daten deutlich älter als die Objekte sind, aus denen sie gewonnen wurden, und auch älter als die gesamte Siedlung, weshalb man sie verwerfen muß. Jedoch bezeugen sie die Gleichzeitigkeit des Grabenobjektes und des Bestattungsplatzes im Brunnen. Dieser datiert aufgrund dendrochronologischer Daten und der Sedimentanalyse frühestens in die zweite Hälfte des 5. Jhs.

Das Grabenobjekt muß man daher in den selben Zeitraum setzen, d.h. in die zweite Hälfte des 5 . Jhs. Es sei angemerkt, daß nach den gegenwärtig bestehenden Ansichten im Gebiet Großpolens in jener Zeit eine absolute Siedlungsleere bestanden haben soll, die aus der Abwanderung der germanischen Bevölkerung resultiert. Die Datierung der Grabkomplexe in Konarzewo zeugt davon, daß die Situation sich anders darstellt.

\section{Das grabenformige Sepulkralobjekt im Vergleich}

Grabanlagen in Form von Gräben treten in Polen in zwei unterschiedlichen chronologischen Abschnitten auf. Die Befunde der älteren Gruppe sind vom keltischen Gräberfeld in Kietrz und von Nekropolen der Przeworsk-Kultur in Kleinpolen, auf der nördlichen Seite der Weichsel, bekannt. Sie werden in die späte vorrömische Eisenzeit und in die ältere Kaiserzeit datiert und aus keltischer Tradition hergeleitet. Die Gräber des jüngeren Horizontes treten in der Schlußphase der Przeworsk-Kultur auf. Sie sind von vier Nekropolen in der Umgebung von Częstochowa und aus Oberschlesien bekannt. Ihre Genese und ihr Verhältnis zu den Objekten der älteren Gruppe wurden bisher nicht untersucht: zudem wurden sie nur in Vorberichten publiziert. Beide Gruppen trennt ein mehrere Jahrhunderte umfassender Zeitraum (wenigstens 250 Jahre). In Rybno, Kr. Kłobuck, und in Izbicko, Kr. Strzelce Opolskic, wurde jeweils ein Grab freigelegt, in Opatów, Kr. Częstochowa, fand man mehrere und in Żabieniec, Kr. Częstochowa, 12 Gräber. Alle Anlagen haben mehrheitlich eine ähnliche Form und einander angenäherte Ausmaße (ca. 2,2 2,5 m). Sie unterscheiden sich aber deutlich in der Art der Verfüllung, der Ausstattung und der Zahl der bestatteten Personen (eine oder mehrere).

In der von $\mathrm{K}$. Godlowski vorgestellten und von M. Gedl wiederholten Interpretation umfaßte der Graben den Scheiterhaufen und nach dem Brand wurden dessen Überreste zusammen mit den Knochen und Beigaben in den Graben geräumt. Diese Deutung weckt Zweifel. Sie stützt sich nur auf ein Beispiel (Żabieniec, Grab 17), bei dem in der vom Graben umschlossenen Innenfläche eine Schicht gebrannten Bodens auftrat. Jedoch war lediglich ein kleiner Teil der Innenfläche gebrannt, außerdem wurde hier nur eine Person bestattet. Nach unserer Überzeugung handelt es sich um zielgerichtete Gräber mit Ein- oder Mehrfachbestattungen, in welchen einmalig 
die Scheiterhaufenrückstände und der Leichenbrand oder die Leichenbrände deponiert wurden. Sie unterscheiden sich auch hinsichtlich der Ausstattung. Das Objekt in Konarzewo ist deutlich von den übrigen Gräbern verschieden, da hier die Toten in Urnen beigesetzt wurden und auch Leichenbrand außerhalb des Grabens auftrat. Nur hier existierte ein den ganzen Komplex uberdeckendes Steinpflaster. Am ähnlichsten ist das Grab aus Izbicko. In dessen Grabenverfüllung trat auch Branderde auf, im Bereich des Grabens bestanden fünf Leichenbrandkonzentrationen geringer Menge. In zweien lagen Metallgegenstände und Keramik, in den drei übrigen nur Scherben.

Das Objekt in Konarzewo unterscheidet sich in drei Merkmalen von den übrigen: In der Verfüllung des Grabens trat ausschließlich Branderde auf, es ist de facto eine Art Brandschüttungsgrab und es war mit einem Steinpflaster überdeckt. Außerdem existierten hier eigentlich keine Grabbeigaben bei den einzelnen Bestattungen, denn die Metalle lagen, nicht mit einer Bestattung verbunden, in der Schicht über dem Grab. Insgesamt kann man schlußfolgern, daß es sich bei den genannten Anlagen um ähnliche Objekte mit identischer Form, gleichen Ausmaßen und teilweise mit gleicher Verfüllung handelt. Hinsichtlich der Art der Beisetzungen und der Ausstattung sind sie hingegen sehr verschieden.

Es ist schwer die These zu akzeptieren, daß die Anlagen im Ergebnis eines einfachen Beiseiteräumens der Scheiterhaufenrückstände in einen vorher dafür angelegten Graben entstanden. Im Falle von Konarzewo kann man das völlig ausschließen und ein großer Teil von ihnen hat den Charakter von Mehrfachbestattungen. Wir haben es also mit einem eigenständigen Grabtyp zu tun, der Teil sich stark differenzierender Bestattungssitten in der Schlußphase der Przeworsk-Kultur ist, was zu archäologisch schwer faßbaren Formen dieser Sitten führt.

Übersetzt von Jan Schuster 